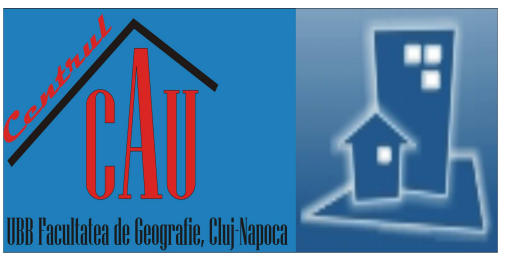

\title{
Population Dynamics in the Coastal Urban Settlements of the Baltic Sea Region
}

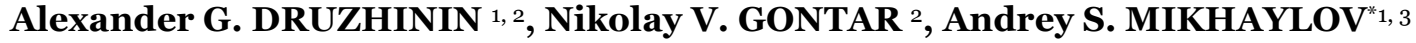 \\ * Corresponding author \\ ${ }^{1}$ Immanuel Kant Baltic Federal University, Kaliningrad, RUSSIA \\ ${ }^{2}$ Southern Federal University, Rostov-on-Don, RUSSIA \\ ${ }_{3}^{3}$ Saint Petersburg Electrotechnical University “LETI”, Saint-Petersburg, RUSSIA \\ E-mail: alexdru9@gmail.com, passato1@mail.ru,mikhailov.andrey@yahoo.com \\ DOI: 10.24193/JSSP.2019.1.06 \\ https://doi.org/10.24193/JSSP.2019.1.06
}

K e y w o r d s: population dynamics, Baltic Sea Region (BSR), coastal region, coastal settlement, urban settlement, settlement patterns

\begin{abstract}
A B S T RA C T
The study is focused on providing an in-depth understanding of the development trajectories of the post-Soviet urban settlements in the Baltic Sea region. The main goal is to specify the particularities of population dynamics in coastal areas and provide the assessment of coastalization. The research scope covers the area of the Baltic Sea macro-region, including the entire territories of the Baltic States (Estonia, Latvia, and Lithuania) and three Scandinavian countries (Denmark, Finland, and Sweden), the northern lands of Germany (Mecklenburg-West Pomerania, Schleswig-Holstein) and Poland (Pomerania, West Pomerania), as well as the north-western part of Russia (the city of St. Petersburg, Leningrad and Kaliningrad regions). The research methodology is focused on cities with over 50,000 inhabitants and a detailed study of settlements with over 100,000 people covering a period from 1990 to 2016. The results support the typology of countries by the level of coastalization - pronounced (Denmark, Sweden, Finland, Estonia, Latvia), moderate (Germany, Lithuania, Poland), and differentiated (Russia). Urban settlements with more than 100,000 inhabitants are further classified into demographically stable and depopulating. Population dynamics and economic development is also analyzed against the background of nation-wide growth or decline trends, resulting in a classification.
\end{abstract}

\section{INTRODUCTION}

The Baltic Sea region (BSR) is one of the most developed and sustainable transnational aquaticterrestrial systems in the world. The profound global geopolitical and geo-economic shifts of the late $20^{\text {th }}-$ early $21^{\text {st }}$ centuries have considerably transformed its socio-economic status affecting Russia and other former Soviet republics, countries of the socialist camp and post-industrial economies of Northern Europe. Scholars link the specific nature of the demographic and urbanization processes in the countries adjacent to the Baltic Sea to their macro-regional characteristics and to the fact that they are a part of the Baltic region (Fedorov et al., 2019; Kirch, 2018; Maksimtsev et al.,
2017; Mezhevich et al., 2016; Palmowski and Tarkowski, 2018). The marine factor is an important prerequisite for the development of the BSR countries. The impact of the sea on the economy and settlement patterns has received considerable attention in recent years. Numerous scholars indicate that coastal areas are attractive to population and industry, resulting in impressive density figures around the globe. Estimations on the share of the world's population residing in coastal territories range from two to three times the global average values (Amos et al., 2013; Creel, 2003; Crossland and Baird, 2005; Salvati and Forino, 2014; Small and Nicholls, 2003).

Discrepancies occur due to variations in the delimitation principles of the coastal zone (including 
altitude), research period, and source of data used. For example, having a broad scope over the Mediterranean countries, Cori (1999) estimates that the coastal population accounts for $10 \%$ of the total, whereas focusing on a coastal zone of 3-mile wide, Suárez de Vivero and Rodríguez Mateos (2005) present the share of the coastal population as being $60 \%$ of the Mediterranean coast. Apart from the remoteness of the land-water boundary, settlement patterns and the economic structure are often taken into consideration as delimitation principles. Scholars trace the coastalization of human activities that benefit from positive externalities of coastal location: marine resources, trade routes, tourism (Blackburn and Marques, 2013). Thus, as reasonably noted by Kildow and McIlgorm (2010), many marine-related activities, such as boat building, seafood processing, maritime research, etc. may be located at a considerable distance from the coast, widening the limits of the "coastal" area. However, coastal urbanization assessment needs to be approached with caution since the "coastal sprawl" is a highly divergent process (Beach, 2002). Mee (2012) notes that, on one hand, there are large megalopolises adjacent to the sea and ocean shores throughout the world and, on the other hand, coastal areas often appear to be a hostile environment. Climatic conditions retain to be a critical factor in the development of coastal areas, while household dependence on marine bio-resources is decreasing. Hence, the perception that all "rush to the coast" (McFadden, 2007) and that coastal zones worldwide are "over-crowded, overdeveloped, and over-exploited" (Hinrichsen, 1996) is incorrect.

Since coastalization predominantly deals with a socio-economic domain (Mikhaylov et al., 2018), it is important to consider the development trajectory of the macro-region. In the context of the BSR countries, urban dynamics and settlement patterns are a comprehensive reflection of the specific economic and political changes that have occurred in the region during the last 30 years (Hanell and Nielsen, 2000; Hanell and Nielsen, 2002; et al., Korcelli, 2002). As stated by Druzhinin (2016), the development of the coastal settlement network across the Baltic Sea varies throughout the BSR countries. Among the factors affecting the residential structure across BSR are the significant changes in the demographic profile (Berzins and Zvidrins, 2011; Hanell, 2000; Manakov et al., 2017; Michalski, 2001), the shift in the economy structure of the post-Soviet space (Glinkina and Kulikova, 2016; Kuznetsova, 2013; Sluka and Ivanov, 2014; Ubarevičienè and Burneika, 2015), and the coastal location of individual countries and regions. The coastal urban settlements of the BSR have become a particular subject for classification and analysis (Fedorov et al., 2017; Borodina, 2016; Enyedi, 1996; Lachininsky and Semenova, 2015), including the ones based on the level of metropolization (Druzhinin, 2014) and transnational cooperation (Palmowski and Tarkowski 2018; Bussmann and Nickel, 2018; Heininen, 2017; Pikner, 2008). Regional and local differences in population dynamics of coastal territories illustrate the centreperiphery gradients within the BSR, indicating the discreteness of its economic and socio-cultural space.

The study seeks to identify the patterns of population dynamics in the BSR while giving specific attention to coastal urban settlements. The following section describes the methodology for the study. Section 3 provides the empirical results presented in a sequential order starting with general socio-economic dynamics of states, followed by data on urban settlements. The paper closes with a summary of key findings and conclusions.

\section{METHODOLOGY}

An in-depth understanding of the development trajectories of the coastal urban settlements in the BSR during the post-Soviet period requires an accurate demarcation of the research area and careful data selection. The general criteria for including a region or a country into the BSR are extensively discussed in scholarly literature, including contemplations over the Baltic Sea catchment area limits, settlement patterns and others (Mezhevich et al., 2016; Palmowski and Tarkowski, 2018; Fedorov and Korneevets, 1999).

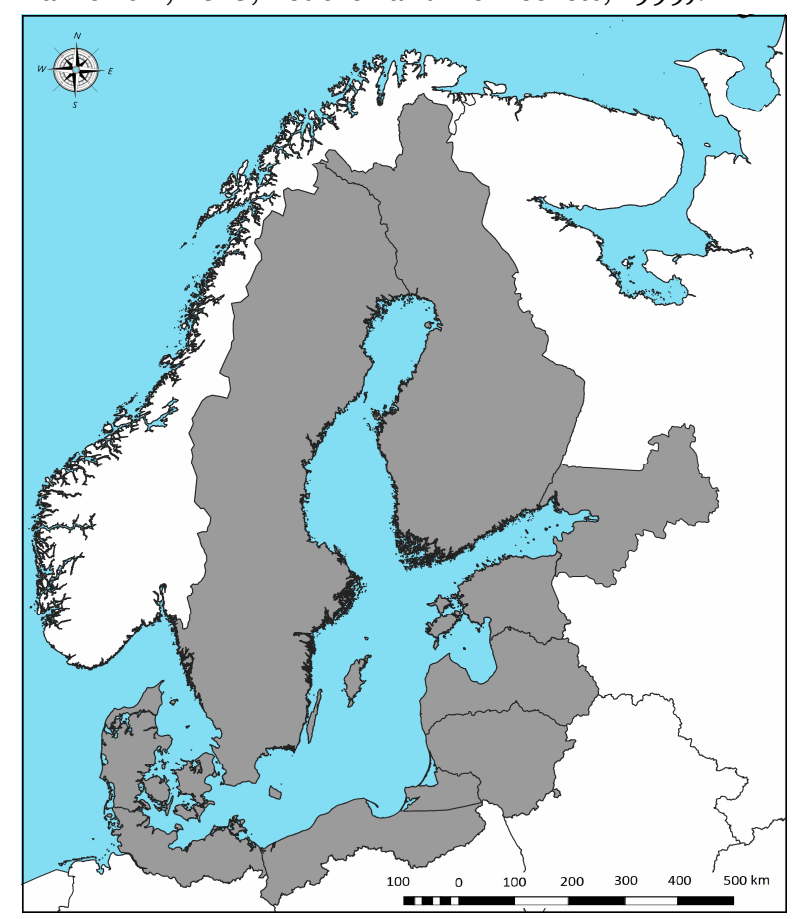

Fig. 1. The Baltic Sea region.

The adopted definition of the BSR implies a study area that includes the entire territories of the Baltic States (Estonia, Latvia, and Lithuania) and Scandinavia in its broad interpretation (Denmark, 
Finland, and Sweden), the northern lands of Germany (Mecklenburg-West Pomerania, Schleswig-Holstein) and Poland (Pomerania, West Pomerania), as well as the north-western part of Russia (the city of St. Petersburg, Leningrad region, Kaliningrad region) - see Figure 1.

The demarcation principles selected for setting the spatial scope of the study are based on the European Union perspective in defining coastal regions, i.e. the regions of the Baltic Sea countries having significant social and economic ties to the sea (Collet, 2010). In this paper, the minimum population threshold set for the urban settlement assessment is 50,000 people. A total of 115 urban settlements are analysed. Their distribution is uneven, as follows: Sweden -46 , Finland - 15 and Denmark (incl. parts of Greater Copenhagen) -15 , Germany - 10, Russia - 8, Poland - 8, Lithuania - 6, Latvia - 4, Estonia - 3. Smaller settlements often do not feature a full spectrum of functions to consider them as coastal in terms of socio-economic profile, thus, they were excluded from the study. Focusing on the coastal potential, several coastal metropolitan areas with a population of over 100,000 people were selected for further urban dynamics analysis. The preliminary analysis is presented by macro-level statistics on economic and demographic indicators of BSR countries allowing to characterize national trends as a condition for the development of coastal regions and the respective coastal urban settlements. The World Bank database (World Bank, 2018) was used as the main source of statistical data (including the national rates of urbanization and urban population growth). At the regional level, the paper provides an analysis of the Eurostat data on NUTS 2 regions and metropolitan areas (Eurostat, 2018), i.e. the largest Baltic coastal centres (the NUTS 2 statistics classification corresponds to the total territory of each of the Baltic States, which is a research limitation). In case of statistical data inconsistency, the preference was given to the national statistics data and population censuses (National
Census Database, 2018; Rosstat, 2018; Statistics Lithuania, 2018).

The baseline years applied are 1990, 2000, 2005, 2010, and 2016. Data for 1995 was used as supplementary information during the refinement and augmentation of data for individual cities. In some cases, data from the adjacent periods was used, depending on the national population census conducted. For instance, the initial indices for Estonia, Latvia, and Lithuania were based on the data of the 1989 Soviet census (instead of 1990); the 2001 census data was also used to compile indices for Lithuania (instead of 2000). In some cases, when data for individual cities was unavailable, the database was supplemented by using extrapolation tools and available data sets for urban dynamics in cities of the same regions. Data for non-capital cities was augmented by drawing on the dynamics of cities with similar status and population (instead of data on capital cities) to ensure the relevance of the data obtained. In total, less than $10 \%$ of the data was refined or augmented.

\section{RESULTS AND DISCUSSION}

\subsection{Countrywide assessment of socio-economic dynamics in the Baltic Sea region}

The total demographic potential of the BSR has not changed much over the analyzed period with 292.5 million people being registered in 1990 and 292.1 in 2016. Russia and Germany are the two dominant demographic poles in the macro-region with a total population of more than 220 million people (140 and 80 million people respectively), followed by Poland with 38 million people. However, only a part of these countries' population is located in the BSR area, which should be taken into consideration. During the postSoviet period, heterogeneous demographic trends have developed in the BSR countries (Table 1).

Table 1. Total population change in the Baltic Sea region (\%).

\begin{tabular}{|c|c|c|c|c|c|}
\hline Country & 1990-1995 & $1995-2000$ & $\begin{array}{c}\text { Period } \\
2000-2005\end{array}$ & $2005-2010$ & 2010-2016 \\
\hline Denmark & 1.8 & 2.0 & 1.5 & 2.4 & 3.3 \\
\hline Estonia & -8.4 & -2.8 & -3.0 & -1.7 & -1.2 \\
\hline Finland & 2.4 & 1.3 & 1.4 & 2.2 & 2.5 \\
\hline Germany & 2.8 & 0.7 & 0.3 & -0.8 & 0.9 \\
\hline Latvia & -6.7 & -4.7 & -5.4 & -6.3 & -6.6 \\
\hline Lithuania & -1.9 & -3.6 & -5.1 & -6.8 & -7.4 \\
\hline Poland & 1.3 & -0.9 & -0.2 & -0.3 & -0.2 \\
\hline Russia & 0.1 & -1.2 & -2.1 & -0.5 & 1.0 \\
\hline Sweden & 3.1 & 0.5 & 1.8 & 3.9 & 5.8 \\
\hline
\end{tabular}

Between 1990 and 2016, the Baltic States have experienced significant population reduction. The population in Estonia has declined by more than $16 \%$, in Lithuania by over one-fifth, and in Latvia by over one-quarter. On the other hand, the population in Denmark and Sweden has increased considerably (by 
$11.4 \%$ and $15.9 \%$ respectively). Migration is the main reason for population growth in the Nordic countries and Germany featuring a considerable influx of migrants in 2015 and 2016. While Estonia suffered a dramatic population decline during the first five postSoviet years, Russia experienced the greatest fall in 2000-2005. Russia and Germany made a demographic recovery in the period 2010-2016, while in Sweden,
Finland and Denmark the population has been growing incrementally since 2000. Generally, demographic trends predominantly depend on economic factors acting as a magnet for migrants who have dramatically changed the demographic landscape of this macroregion (Kirch, 2018). The BSR economic divergence and the shift of balance are reflected in the values of the gross domestic product (GDP) (Table 2).

Table 2. Welfare distribution in the Baltic Sea region.

\begin{tabular}{|c|c|c|c|c|c|c|c|c|}
\hline \multirow{2}{*}{ Country } & \multicolumn{5}{|c|}{ GDP (billion USD, current prices) } & \multirow{2}{*}{$\begin{array}{l}\text { GDP growth } \\
\text { in 1995-2016 }\end{array}$} & \multicolumn{2}{|c|}{ Share of the BSR GDP $(\%)$} \\
\hline & 1995* & 2000 & 2005 & 2010 & 2016 & & 1995 & 2016 \\
\hline Germany & 2591.6 & 1949.9 & 2861.4 & 3417.1 & 3477.8 & 1.34 & 69.5 & 54.5 \\
\hline Russia & 395.5 & 259.7 & 764.0 & 1524.9 & 1283.2 & 3.24 & 10.6 & 20.1 \\
\hline Sweden & 264.1 & 259.8 & 389.0 & 488.4 & 514.5 & 1.95 & 7.1 & 8.1 \\
\hline Poland & 142.1 & 171.9 & 306.1 & 479.3 & 471.4 & 3.32 & 3.8 & 7.4 \\
\hline Denmark & 185.0 & 164.2 & 264.5 & 322.0 & 306.9 & 1.66 & 5.0 & 4.8 \\
\hline Finland & 134.2 & 125.5 & 204.4 & 247.8 & 238.7 & 1.78 & 3.6 & 3.7 \\
\hline Lithuania & 7.9 & 11.5 & 26.1 & 37.1 & 42.8 & 5.43 & 0.2 & 0.7 \\
\hline Latvia & 5.8 & 7.9 & 16.9 & 23.8 & 27.6 & 4.76 & 0.2 & 0.4 \\
\hline Estonia & 4.4 & 5.7 & 14.0 & 19.5 & 23.3 & 5.34 & 0.1 & 0.4 \\
\hline Total & 3730.5 & 2956.2 & 4846.5 & 6559.8 & 6386.0 & 1.71 & 100.0 & 100.0 \\
\hline
\end{tabular}

Note: *the World Bank GDP statistics for the Baltic States - Estonia, Latvia, Lithuania, and for the united Germany starts in 1995.

Calculations suggest that, during the studied period, the region's GDP has almost doubled; the Baltic States, as well as Poland and Russia, outperformed other countries in terms of growth rate. Despite the active growth, the Baltic States produced less than $1 \%$ of the region's GDP each. Germany remains to be the largest economy in the regional GDP, although featuring a significant reduction in its share in favour of Russia and Poland. The per capita indicators of the BSR states had similar trajectories over the period, being convergent into two groups (Fig. 2).

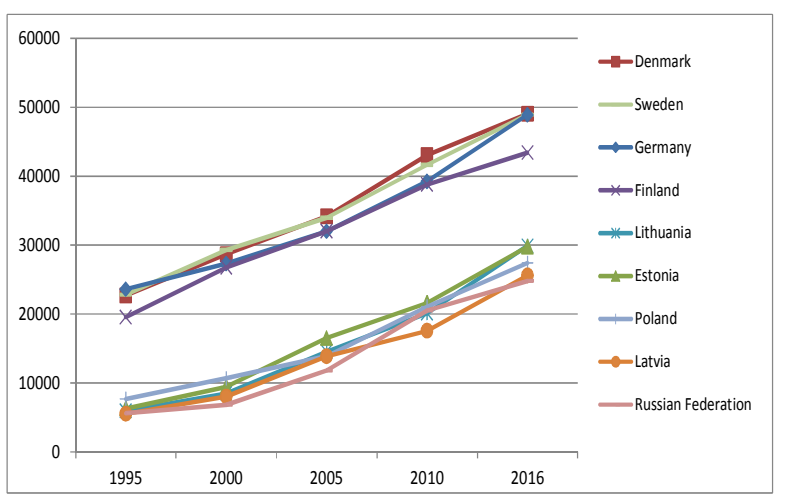

Fig. 2. GDP per capita by PPP (USD) (source: based on World Bank, 2018).

According to statistics, the difference between the maximum and the minimum value for GDP per capita in the region in 1995 was of 4.3. By 2016, the difference halved, with Denmark, Sweden and Germany 64 showing the highest values and Russia showing the lowest due to an almost twofold drop in the exchange rate of the national currency since 2014. In general, the GDP per capita in the region increased 2.7-fold from 13.3 to 36.4 thousand USD, while the usual centre periphery gradient of population flow remained the same. Thus, differences in the level and dynamics of territorial development are expected, while some convergence is expected within two broad groups (Fig. 2).

\subsection{Coastal urban settlements in the Baltic Sea region}

The coastal regions of the BSR countries differ in terms of level of development and demographic potential, and also regarding their position in the national centre-periphery systems. For instance, St. Petersburg is rightfully the second capital of Russia, and Kaliningrad is a meaningful strategic enclave, while German bundeslands and Polish voivodeships on the Baltic Sea generally fall into the category of national peripheries.

The geography of coastal urbanization is an indication of the national demographic dynamics and reflects the role of thalasso-attractiveness (i.e. coastalization) in the spatial organization of economies. According to the latter, the BSR can be divided into the following groups (Fedorov et al., 2017): countries with pronounced coastalization (Denmark, Sweden, Finland, 
Estonia, Latvia); countries with less profound effect of the proximity to the sea (Germany, Lithuania, Poland); countries with strong differentiation of the territory in terms of coastalization (Russia). Table 3 shows the differentiation of urbanization parameters by the three groups of countries.

Table 3. Urban population dynamics in 1990-2016 (\%).

\begin{tabular}{|c|c|c|c|c|}
\hline \multirow{2}{*}{ Country } & \multicolumn{2}{|c|}{ Urban population share } & \multirow{2}{*}{$\begin{array}{l}\text { Change in urban } \\
\text { population share }\end{array}$} & \multirow{2}{*}{$\begin{array}{c}\text { Average annual rate of } \\
\text { change in urban } \\
\text { population share }\end{array}$} \\
\hline & 1990 & 2016 & & \\
\hline \multicolumn{5}{|c|}{ Pronounced coastalization } \\
\hline Denmark & 84.8 & 87.8 & 3.0 & 0.54 \\
\hline Sweden & 83.1 & 86.0 & 2.9 & 0.70 \\
\hline Finland & 79.4 & 84.4 & 5.0 & 0.63 \\
\hline Estonia & 71.2 & 67.5 & -3.8 & -0.86 \\
\hline Latvia & 69.3 & 67.4 & -1.9 & -1.24 \\
\hline \multicolumn{5}{|c|}{ Moderate coastalization } \\
\hline Germany & 73.1 & 75.5 & 2.4 & 0.30 \\
\hline Lithuania & 67.6 & 66.5 & -1.1 & -0.99 \\
\hline Poland & 61.3 & 60.5 & -0.7 & -0.04 \\
\hline \multicolumn{5}{|c|}{ Differentiated coastalization } \\
\hline Russia & 73.4 & 74.1 & 0.7 & -0.05 \\
\hline
\end{tabular}

Table 4. Population dynamics in the NUTS-2 coastal regions of the Baltic Sea region

\begin{tabular}{|c|c|c|c|c|c|}
\hline Region & 2006 & 2010 & 2015 & 2017 & $\begin{array}{l}\text { Growth } \\
\text { rate, } \\
\text { 2006-2017 } \\
(\%)\end{array}$ \\
\hline Hovedstaden (DK) & $1,636,749$ & $1,680,271$ & $1,768,125$ & $1,807,404$ & 10.43 \\
\hline Sjælland (DK) & 816,118 & 820,564 & 820,480 & 832,553 & 2.01 \\
\hline Syddanmark (DK) & $1,189,817$ & $1,200,277$ & $1,205,728$ & $1,217,224$ & 2.30 \\
\hline Midtjylland (DK) & $1,227,428$ & $1,253,998$ & $1,282,750$ & $1,304,253$ & 6.26 \\
\hline Nordjylland (DK) & 576,972 & 579,628 & 582,632 & 587,335 & 1.80 \\
\hline Estonia (ES) & $1,350,700$ & $1,333,290$ & $1,314,870$ & $1,315,635$ & -2.60 \\
\hline Latvia (LV) & $2,227,874$ & $2,120,504$ & $1,986,096$ & $1,950,116$ & -12.47 \\
\hline Länsi-Suomi (FI) & $1,334,293$ & $1,355,168$ & $1,377,281$ & $1,380,593$ & 3.47 \\
\hline Helsinki-Uusimaa (FI) & $1,452,083$ & $1,517,542$ & $1,603,388$ & $1,638,293$ & 12.82 \\
\hline Etelä-Suomi (FI) & $1,143,740$ & $1,154,648$ & $1,161,706$ & $1,159,174$ & 1.35 \\
\hline Pohjois-ja Itä-Suomi (FI) & $1,298,698$ & $1,296,335$ & $1,300,462$ & $1,296,023$ & -0.21 \\
\hline Åland (FI) & 26,766 & 27,734 & 28,916 & 29,214 & 9.15 \\
\hline Stockholm (SE) & $1,889,945$ & $2,019,182$ & $2,198,044$ & $2,269,060$ & 20.06 \\
\hline Östra Mellansverige (SE) & $1,518,077$ & $1,558,292$ & $1,621,566$ & $1,664,145$ & 9.62 \\
\hline Småland med öarna (SE) & 800,054 & 810,066 & 826,243 & 847,667 & 5.95 \\
\hline Sydsverige (SE) & $1,320,160$ & $1,383,653$ & $1,443,065$ & $1,483,018$ & 12.34 \\
\hline Västsverige (SE) & $1,814,323$ & $1,866,283$ & $1,942,677$ & $1,992,116$ & 9.80 \\
\hline Norra Mellansverige (SE) & 825,037 & 825,931 & 833,585 & 848,451 & 2.84 \\
\hline Mellersta Norrland (SE) & 370,764 & 369,708 & 369,826 & 374,245 & 0.94 \\
\hline Övre Norrland (SE) & 509,392 & 507,567 & 512,349 & 516,451 & 1.39 \\
\hline Mecklenburg-West Pomerania (DE) & $1,707,266$ & $1,651,216$ & $1,599,138$ & $1,610,674$ & -5.66 \\
\hline Schleswig-Holstein (DE) & $2,832,950$ & $2,832,027$ & $2,830,864$ & $2,881,926$ & 1.73 \\
\hline Lithuania (LT) & $3,289,835$ & $3,141,976$ & $2,921,262$ & $2,847,904$ & -13.43 \\
\hline West Pomerania (PL) & $1,694,178$ & $1,696,985$ & $1,688,486$ & $1,681,246$ & -0.76 \\
\hline Pomerania (PL) & $2,199,043$ & $2,234,955$ & $2,271,559$ & $2,285,800$ & 3.95 \\
\hline St. Petersburg \& Leningrad region (RU) & $2,936,732$ & $3,162,688$ & $3,416,150$ & $3,489,663$ & 18.83 \\
\hline Kaliningrad region (RU) & 939,887 & 941,873 & 968,944 & 986,261 & 4.93 \\
\hline
\end{tabular}

The data shows that classification based on coastal proximity introduces only fragmentary differences in the level and pace of urbanization. In general, it is possible to declare pervasive deurbanization. As data indicate, the urban population decline is a widespread phenomenon in Russia, in the 
post-Soviet space and in the former socialist camp. To a certain extent, the entry of the former socialist countries into the European Union served as the trigger for this process, as it opened up the possibility for mass labour migration, affecting primarily the urban population with its more mobile and skilled workers. The Baltic States of Estonia, Latvia, Lithuania, and Poland became EU members only by 2004, nearly a decade later than Scandinavian countries, which affected the patterns of their development trajectory. Table 4 indicates the population dynamics in the coastal areas of the BSR.

The coastal urban settlements of the BSR countries demonstrate their significant dependence on both the centre-periphery status and history (i.e. the "old" and the "new" West). Germany is a good example of the latter since two of its coastal areas were divided between the former Federal Republic of Germany (FRG) and the German Democratic Republic (GDR). In the period 1990-2016, the urban settlements of both regions were affected by depopulation. For instance, Kiel, the centre of the western state of SchleswigHolstein, lost $3 \%$ of its population, whilst Rostock, the centre of Mecklenburg-West Pomerania, lost about $17 \%$. The urban population decline in the western state ranged from $3 \%$ to $6.3 \%$, while in the eastern one was between 13.5 and $28.8 \%$ (with Neubrandenburg suffering peak losses). Depopulation is the general trend for the east of the country. In the post-Soviet period, its urban population has decreased by $20 \%$. In half of the urban settlements, the decrease was of even more than $20 \%$. One of the reasons was the industry modernization leading to a reduction in employment. A particular example is Lauzitc thermal power station with 10,000 people of the GDR being employed; today it is the state-of-the-art and one of the largest plants with a total of 250 employees. Another reason for depopulation is population ageing and increasing mortality rate. A significant factor is the desire of people to move to larger cities. On the territory of the former GDR, there are now only four urbanization centres left - Berlin, Dresden, Leipzig and Jena. A reason for the current break is the launch of the 'Strengthen the strengths' initiative in 26 cities of the eastern state of Brandenburg. Drawing on the example of the coastal urban settlements of Germany, a 5\% reduction in the population can be attributed to the peripheral status of the territories; however, a 10-20\% additional reduction of the eastern urban population is a consequence of post-socialist transformation. The Baltic States confirm this assumption. Their cities have undergone significant depopulation. The capitals of Estonia and Latvia experienced less reduction than other urban settlements in these countries indicating a redistribution of the population. By 2016, the total population of cities in Latvia decreased by $30.7 \%$, in Lithuania - by $19.8 \%$, in Estonia - by $15.1 \%$. In fact, such a dramatic fall is typical, for example, of the Latvian cities of Liepaja (from 114,462 to 70,630 people), Daugavpils (from 126,680 to 85,858 people), and Riga (from 915,106 to 639,630 people).

In Poland with its famous 'shock therapy' strategy of transition from socialism to capitalism, the urban population of two coastal voivodships decreased by $1.8 \%$. The $10 \%$ population reduction in Stupsk is the exception to the rule; as, at the same time, the population of Wejherowo increased by $5.8 \%$ in 19902016. The population decline in Gdansk and Szczecin, the largest coastal centres of Poland, is negligible.

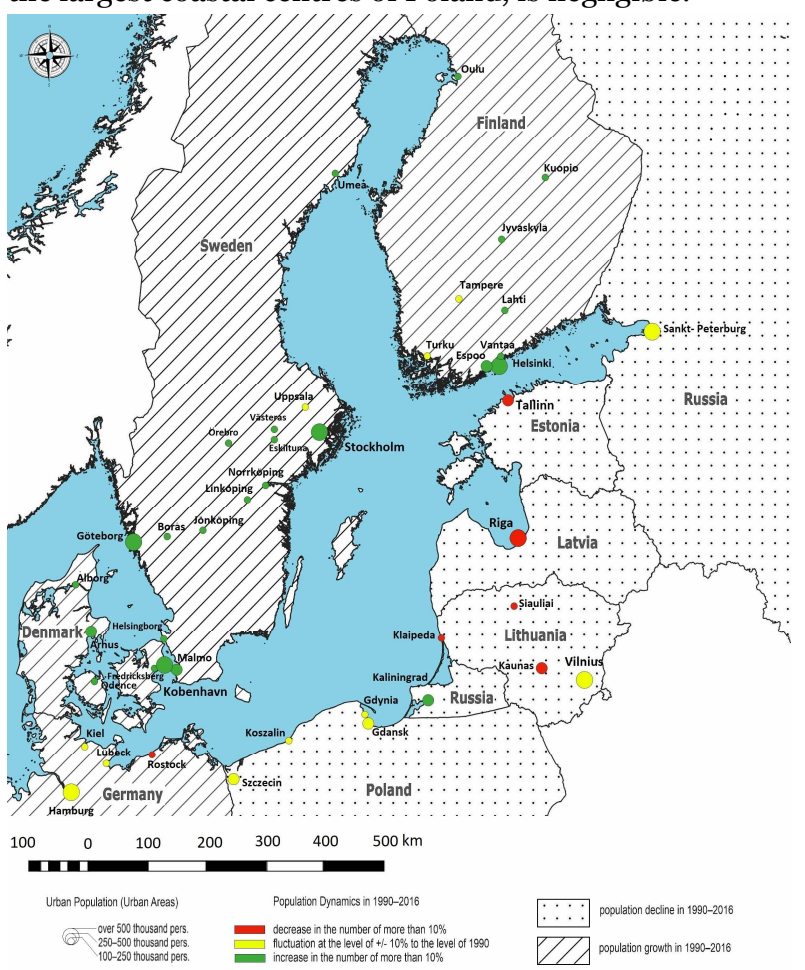

Fig. 3. Population dynamics of the Baltic coastal urban settlements in 1990-2016.

The specific factor that has affected the demographic dynamics of the Baltic coastal urban settlements of Russia is the growth of their importance in the post-Soviet period associated with the fact that the country has lost some major ports and coastal areas. Additional factors contributing to the growth include the reorientation of raw materials exports from the ports of the Baltic States to new ports near St. Petersburg, the dramatic increase in raw materials exports and import, the export of manufactured goods, as well as the reindustrialization related to the marine factor. As a result, during the period from 1989 until 2016 the population of some coastal urban settlements in the Russian Federation has more than doubled (Vsevolozhsk showed a 2.1-fold increase, Sertolovo showed a 2.9-fold increase). However, it should be noted that these settlements are not large. On average, in the given period, the population of the relevant urban settlements has grown by $6.2 \%$ (St. Petersburg - by 
4.5\%, Kaliningrad - by 13.5\%). However, Vyborg and Kirishi demonstrated a slight decrease (both by $3 \%$ ).

The rate of change in the population of the coastal cities of the former Soviet Union in the Baltic States was highly unstable over the period. In 19902000 the population of the coastal cities of Eastern Germany and the three countries of the Soviet Baltics declined considerably - by $8 \%$ in Lithuania and by $16-$ $19 \%$ in the other two countries. In 2010-2016, the population continued to decline only in Latvia (by 6.2\%) and Lithuania (by 5.7\%), while in the other two countries there was an increase. In the coastal cities of Poland in 1990-2016 population decline did not exceed $2 \%$, while in Russia, the coastal cities at the Baltic Sea, which lost about $6 \%$ of the population in 1990-2005, showed an increase of over $12 \%$ in 2005-2016.

Figure 3 further illustrates a significant population decline in all urban settlements located in the territory of the former socialist camp, except for Russia and Poland. It is worth mentioning, that the rate of the population loss has changed upon the entry of the Baltic States into the EU: since 2005, Latvia and Lithuania have suffered a new upsurge of the population outflow. Estonia did not experience it due to the fact that it has achieved economic stability earlier since it was a precondition for the Eurozone (the euro was put into circulation in 2011, while in Latvia and Lithuania it occurred in 2014 and 2015 respectively). Zero population outflow from the coastal urban settlements in Poland is explained by the size of the economy and by the relatively fast pace of the transformation process. Demographic recovery of the Russian urban settlements on the Baltic coast coincided with the resource-based economic growth of the mid2000 .

The coastal urban settlements of the Old Europe have not felt the effects of economic transformations since 1990; therefore, urbanization has developed progressively and experienced a significant impact of the migration factor. As noted above, the Baltic coastal metropolitan areas of the Old West experienced $3-11 \%$ population increase in $2000-2016$. The Baltic coastal settlements of West Germany lost 4\% of their population in 1990-2016, while the Eastern coastal settlements in Mecklenburg-West Pomerania lost 20\%. During this period, the largest coastal centres of the developed Baltic countries were actively increasing their demographic potential (Table 5).

Table 5. Population dynamics in the largest coastal centres (over 250 thousand people) of the developed Baltic Sea region states (no. of people).

\begin{tabular}{|c|c|c|c|c|c|c|}
\hline City & 1990 & 2000 & 2005 & 2010 & 2016 & $\begin{array}{l}\text { Growth } \\
\text { rate }\end{array}$ \\
\hline Helsinki / Helsingfors & 491,000 & $559,718 *$ & 558,122 & 588,549 & 628,208 & 27.9 \\
\hline Espoo / Esbo & 169,833 & 209,667 & 230,912 & 247,970 & 269,802 & 58.9 \\
\hline Tampere / Tammerfors & 218,722 & 270,753 & 241,130 & 211,507 & 225,118 & 2.9 \\
\hline Turku / Åbo & 205,953 & 239,018 & 207,553 & 176,087 & 185,908 & -9.7 \\
\hline Stockholm & 674,452 & 750,348 & 771,038 & 829,417 & 935,619 & 38.7 \\
\hline Göteborg & $\ldots$ & 466,990 & 484,942 & 507,330 & 556,640 & 19.2 \\
\hline Malmö & $\ldots$ & 259,579 & 271,271 & 293,909 & 328,494 & 26.5 \\
\hline $\begin{array}{l}\text { København (part of Greater } \\
\text { Copenhagen Region) }\end{array}$ & $\ldots$ & $\cdots$ & 498,151 & 528,208 & 591,481 & 18.7 \\
\hline Aarhus & $\ldots$ & $\ldots$ & 233,197 & 242,914 & 264,716 & 13.5 \\
\hline
\end{tabular}

The calculations indicate that, aside from the national population redistribution, presumably explaining the population decrease in Turku, all the largest Baltic coastal centres of the Old Europe demonstrated brisk population growth, largely ensured by the open door policy and the generous social support offered to migrants prior to the migration crisis of 20152016. The large urban settlements in Finland (Oulu, Tampere, and Vantaa) demonstrated unstable dynamics after 1990, although the general demographic trend was upward. The other urban settlements with the population range of 50-250 thousand inhabitants showed an average population increase of $20.1 \%$ in 1990-2016 (including Kotka - 2\%, Lahti - 13.5\%,
Kuopio $-62 \%$, etc.). The population of the Swedish coastal urban settlements (except for the abovementioned Stockholm, Gothenburg and Malmö) has increased by $15.5 \%$ ( $17.9 \%$, if we include the major centres). This seems to indicate the process of urban concentration in Sweden. In the studied period, the population growth in Solna and Naa exceeded 30\%, in 9 other urban settlements (Botkirka, Sollentuna, Hanninge etc.) it was more than 20\%, and in 12 cities (Jönköping, Helsingborg, Linköping, etc.) it was over $15 \%$.

In Denmark, with 15 urban settlements analyzed (as, in fact, all five Danish NUTS 2 level regions have access to the Baltic Sea), all urban 
settlements experienced population growth from 5.1\% to $18.7 \%$ in $2005-2016$. Out of six urban settlements in the urban area of Greater Copenhagen, two had minimal increase, two - medium, two - high, indicating the absence of explicit urban population centralization. The total population growth of the coastal urban settlements in Denmark in 2005-2016 has reached 13\%. During the same period, the urban population growth in Sweden was of $12.7 \%$. Therefore, it is possible to state that during the last eleven years the processes in the countries have synchronized. The extrapolation (taking into account trend inertia and growth factors) points to the increase in the coastal urban population of both Denmark and Sweden by an average of $20 \%$ (with some settlements being above 20\%).

\section{CONCLUSIONS}

The study on the post-Soviet demographic dynamics of the coastal urban settlements in the BSR has revealed a number of features, both with due regard to the countrywide trends and the specifics of coastalization. The differences occur due to the national population dynamics and the development trajectories of key urban centres. The urban settlements within a macro-region generally fall into one of the following types:

I. Demographically stable and growing cities in countries with sustainable population growth (e.g. Nordic capitals, Malmö, Hamburg, etc.). These are urban settlements localized in countries experiencing active population growth (Nordic countries and Germany in particular).

I.a. A subtype characterised by urban depopulation contrasted with the general growth of the national population (e.g. Rostock).

II. Demographically stable and growing cities in countries suffering depopulation. This group includes the urban settlements of Russia and Poland (for instance, St. Petersburg, Kaliningrad, and Gdansk).

III. Cities with declining population in countries suffering depopulation at the national level (Lithuania, Latvia and Estonia).

III.a. A subtype characterized by an urban centre with stable population in a country experiencing population decline (e.g. Vilnius).

The urban population dynamics in the coastal regions of the BSR countries demonstrates multidirectional trends that are subject to the factors associated with changing socio-economic models, the national centre-periphery system and joining the supranational institutes (EU, Eurozone). One of the major trends of the period is the depopulation of the urban settlements in the Baltic States and the eastern part of Germany. At the same time, while the population of coastal urban settlements remained stable in Poland, substantial growth was registered in Russia.
Against this background, the maximum urban population growth is reached in the Nordic countries. Their significant migration attractiveness resulted in the urban population growth in Denmark and Sweden by at least $20 \%$ in this century alone. Over the past three decades, the BSR has been undergoing active formation process within the overall European integration framework. The macro-region is a RussiaEU bipolar structure with substantial sustainable differences in socio-economic and residential dynamics of its national and regional segments. The identified trends in the transformation of cities in the Baltic region are grounded on the differences in the key factors that predetermined transformations in the period after the collapse of the USSR. The coastal cities of the "old" Europe (Western Germany, Scandinavia, Denmark) continued their developmental trends, which supported the "welfare state" with a wide range of guarantees for population. As a result, this led to an explosive influx of migrants in 2015-2016. Both the young population and a significant inflow of migrants after mid-2010s has led to the active growth of population and the preservation of the potential of the capitals and large coastal cities of the countries of the “old” Europe.

The key trend of the cities of the former "socialist" bloc, on the contrary, are the shock changes that led to a sharp change in development conditions, causing de-urbanization (irrespective of individual triggers). In Russia, Eastern Germany and the Baltic States the depopulation was combined with an economic crisis, while the economy of Poland was less affected. However, in the Baltic States, migration losses were significant, both because of the outflow of the Russian population and because of the possibility of labour migration that opened along with the accession to the EU. The process was accompanied by the sharp decline of the urban population, which had detrimental consequences for rural areas.

Today, the growth of commodity exports and the associated explosive development of port and pipeline infrastructure caused both the influx of population and the economic growth in cities of the Baltic coast of Russia. The rest of the BSR does not show similar factors for breaking the established urban development trends, thus, resulting in a fragmentary recovery of the urban population share in Eastern Germany and Estonia, and the preservation of negative (albeit less pronounced) trends in the other Baltic States.

\section{ACKNOWLEDGEMENTS}

The reported study was funded by Russian Science Foundation according to the Research Project No. 19-18-00005 «Eurasian Vector of Russian Marine Economy: Regional Economy Perspective». 


\section{REFERENCES}

Amos C. L., Al Rashidi T., Rakha K., El-Gamily H., Nicholls R. (2013), Sea surface temperature trends in the coastal ocean. Current Development in Geography, 6(1), 1-13.

Beach D. (2002), Coastal Sprawl: the effects of urban design on aquatic ecosystems in the United States. Arlington, VA. Pew Oceans Commission.

Berzins A., Zvidrins P. (2011), Depopulation in the Baltic States. Lithuanian Journal of Statistics, 50(1), 39-48. Blackburn S., Marques C. (2013), Mega-urbanization on the coast. In M. Pelling, S. Blackburn (Eds.), Megacities and the Coast: risk, resilience and transformation. London and New York: Routledge, 25-26.

Borodina T. L. (2016), Typology of the regional dynamics of the population of Russia in the post-Soviet period. In: V.M. Kotlyakov, V.N. Streletsky, O.B. Glezer, S.G. Safronov (eds.) Problems of regional development of Russia. Codex publishing house, 191-208.

Bussmann M., Nickel S. (2018), Transnational cooperation: a network analysis of town twinning in the Baltic Sea region. Journal of Baltic Studies, 49(3), 281303. DOI: https://doi.org/10.1080/01629778.2018. 1447977

Collet I. (2010), Portrait of EU coastal regions No.38. Statistics in focus. Eurostat. European Union. [online], URL: http://ec.europa.eu/eurostat/documents/3217 494/5728589/KS-HA-11-oo1-13-EN.PDF/codd 33edodb2-4d8b-aeo3-26d9bf3e57fc?version=1.0 Accessed on 27.01.2019

Cori B. (1999), Spatial dynamics of Mediterranean coastal regions. Journal of Coastal Conservation, 5, 105112. DOI: https://doi.org/10.1007/BFo2802747.

Creel L. (2003), Ripple effects: population and coastal regions. Population Reference Bureau.

Crossland C. J., Baird D. (2005), The coastal zone a domain of global interactions. In: C. J. Crossland, H. H. Kremer, H. J. Lindeboom, J. I. Marshall Crossland, M. D. A. Le Tissier (eds.), Coastal fluxes in the anthropocene; the land-ocean interactions in the coastal zone project of the international geospherebiosphere programme. Berlin: Springer, 1-37.

Druzhinin A. G. (2014), Metropolises and metropolization in modern Russia: conceptual approaches in the context of political geography. Izvestiya Rossiiskoi Akademii Nauk. Seriya Geograficheskaya, 1, 19-27.

Druzhinin A. G. (2016), Sotsial'no-ekonomicheskoye razvitiye primorskikh territoriy Yevropeyskoy chasti Rossii: faktory, trendy, modeli [Socio-economic development of coastal areas of the European part of Russia: factors, trends, models]. Rostov-on-Don: Southern Federal University.

Enyedi G. (1996), Urbanisation under Socialism. In: G. Andrusz, M. Harloe, I. Szelenyi (eds.) Cities After
Socialism: Urban and Regional Change and Conflict in Post-Socialist Societies. Wiley-Blackwell, 100-118.

Eurostat (2018), European Statistical Office Database URL: https://ec.europa.eu/eurostat/ data/database Accessed on 27.01.2018

Fedorov G. M., Korneevets V. S. (1999), Baltic region: social and economic development and cooperation. Kaliningrad: Yantarnyy skaz. [in Russian].

Fedorov G. M., Zotov S. Yu., Kuznetsova T. Yu., Chasovsky V. I. (2016), Baltic region: its composition and inner structure. Regionalnie isslegovaniya, 2(52), 113-121.

Fedorov G. M., Mikhailov A. S., Kuznetsova T. Yu. (2017), The Influence of the Sea on the Economic Development and Settlement Structure in the Baltic Sea Region. Baltic region, 9(2), 4-18. DOI: https://doi.org/ 10.5922/2079-8555-2017-2-1

Fedorov G. M., Razumovskiy V. M., Kuznetsova T. Yu., Gumeniuk L. G. (2017), Population distribution and change in the coastal Baltic cities. Proceedings of the Russian Geographical Society, 149(6), 14-24.

Glinkina S. P., Kulikova N. V. (2016), The transition of Central and Eastern European countries from socialism to capitalism: peculiarities and results. Moscow: The Institute of Economy RAS.

Hanell T. (2000), Troubling demographic trends in the Baltic Sea Region. North, 11(2-3), 5-11.

Hanell T., Nielsen B. (2000), Urban systems in the Baltic Sea Region. North, 11 (2-3), 18-22.

Hanell T., Nielsen B. (2002), Urban systems in the Baltic Sea Region: Metropolitan regions take the lead. Geographia Polonica, 75 (2), 101-115.

Heininen L. (2017), The Arctic, Baltic, and NorthAtlantic 'cooperative regions' in 'Wider Northern Europe': similarities and differences. Journal of Baltic Studies, $48 \quad$ (4), $435-450 . \quad$ DOI: https://doi.org/10.1080/01629778.2017.1305180

Hinrichsen D. (1996), Coasts in crisis. Issues in Science and Technology, 12 (4), 39-47.

Kildow J. T., McIlgorm A. (2010), The importance of estimating the contribution of the oceans to national economies. Marine Policy, 34 (3), 367-374. DOI: https://doi.org/10.1016/j.marpol.2009.08.006

Kirch A. (2018), 'Knowledge Workers' in the Baltic Sea Region: Comparative Assessment of Innovative Performance of the Countries in the Macro-Region. Baltic Journal of European Studies, 8 (1), 176-196. DOI: https://doi.org/10.1515/bjes-2018-0010

Korcelli P., Groth N. B., Nowosielska E. (2002), National urban systems in the Baltic Sea Region: Trends and challenges. Geographia Polonica, 75 (2), 117-142.

Kuznetsova T. Yu. (2013), Trends and factors of geodemographic development in the Baltic region: regional evaluation. Regionalnie Issledovaniya, 3 (41), 50-57. 
Lachininsky S. S., Semenova I. V. (2015), SanktPeterburgskiy primorskiy region: geoekonomicheskaya transformatsiya territorii [St. Petersburg coastal region: geo-economic transformation of the territory]. SPb.: Lema Publishing House. [in Russian]

Maksimtsev I. A., Mezhevich N. M., Koroleva A. V. (2017), Economic Development of the Baltics and Nordic countries: Characteristics of Economic Models. Baltic region, 9 (1), 60-78. DOI: https://doi.org/ 10.5922/2074-9848-2017-1-4

Manakov A. G., Suvorkov P. J., Stanaitis S. A. (2017), Population Ageing as a Sociodemographic Problem in the Baltic Region. Baltic region, 9 (1), 79-95. DOI: https://doi.org/10.5922/2074-9848-2017-1-5

McFadden L. (2007), Governing Coastal Spaces: The Case of Disappearing Science in Integrated Coastal Zone Management. Coastal Management, 35 (4), 429-443 DOI: http://dx.doi.org/10.108o/o8920750701525768

Mee L. (2012), Between the devil and the deep blue sea: the coastal zone in an era of globalisation. Estuarine, Coastal and Shelf Science, 96, 1-8. http://dx.doi.org/10.1016/j.ecss.2010.02.013

Mezhevich N. M., Kretinin G. V., Fedorov G. M. (2016), Economic and Geographical Structure of the Baltic Sea Region. Baltic region, 8 (3), 11-21. DOI: https://doi.org/10.5922/2079-8555-2016-3-1

Mikhaylov A. S., Mikhaylova A. A., Kuznetsova T. Y. (2018), Coastalization effect and spatial divergence: Segregation of European regions. Ocean and Coastal Management, 161, 57-65. DOI: https://doi.org/10.1016/j.ocecoaman.2018.04.024

Michalski T. (2001), The main demographic and health problems of the former Soviet part of Baltic Europe. In: J. Wendt (ed.), Baltic Europe on the eve of third millennium. Gdańsk: Wydawnictwo Uniwersytetu Gdańskiego, 113-119.

National Census Database (2018), Ethnic composition. URL: http://pop-stat.mashke.org Accessed on 27.01.2018.

Palmowski T., Tarkowski M. (2018), Baltic cooperation in marine spatial planning. Baltic region,
10 (2), 100-113. DOI: https://doi.org/10.5922/20798555-2018-2-7

Pikner T. (2008), Evolving cross-border urban networks: Case studies in the Baltic Sea area. Nordia Geographical Publications, 37 (4), 12-52.

Rosstat (2018), Regiony Rossii. Sotsial'noekonomicheskiye pokazateli (Regions of Russia. Socioeconomic indicators). URL: http://www.gks.ru/wps/ $\mathrm{wcm} /$ connect/rosstat_main/rosstat/ru/statistics/ publications/catalog/doc_1138623506156 Accessed on 27.01.2018.

Salvati L., Forino G. (2014), A 'laboratory' of landscape degradation: social and economic implications for sustainable development in peri-urban areas. Int. J. Innovation and Sustainable Development, 8 (3), 232-249. DOI: https://doi.org/10.1504/IJISD. 2014.066616

Sluka N., Ivanov D. (2014), Demographic Ranking of the Baltic Sea States. Baltic region, 2 (20), 22-34. DOI: https://doi.org/10.5922/2079-8555-2014-2-2

Small C., Nicholls R. J. (2003), A global analysis of human settlement in coastal zones. Journal of Coastal Research, 19 (3), 584-599.

Statistics Lithuania (2018), Results of the 2011 Population and housing Census of the Republic of Lithuania. URL: http://statistics.bookdesign.lt/ ?lang=en Accessed on 27.01.2018.

Suárez de Vivero J. L., Rodríguez Mateos J. C. (2005), Coastal crisis: the failure of coastal management in the Spanish Mediterranean region. Coastal Management, 33 (2), 197-214. https://doi.org/10.108o/08920750590917602

Ubarevičienė R., Burneika D. (2015), Spatial transformation of the economy in the post-communist period: The case of the Vilnius urban region. Geographia Polonica, 88 (1), 143-157.

World Bank (2018), United Nations Population Division. World Urbanization Prospects: 2018 Revision. URL:

https://data.worldbank.org/indicator/SP.URB.TOTL.I N.ZS?view=chart Accessed on 27.01.2018. 